POLICY BRIEFING SERIES

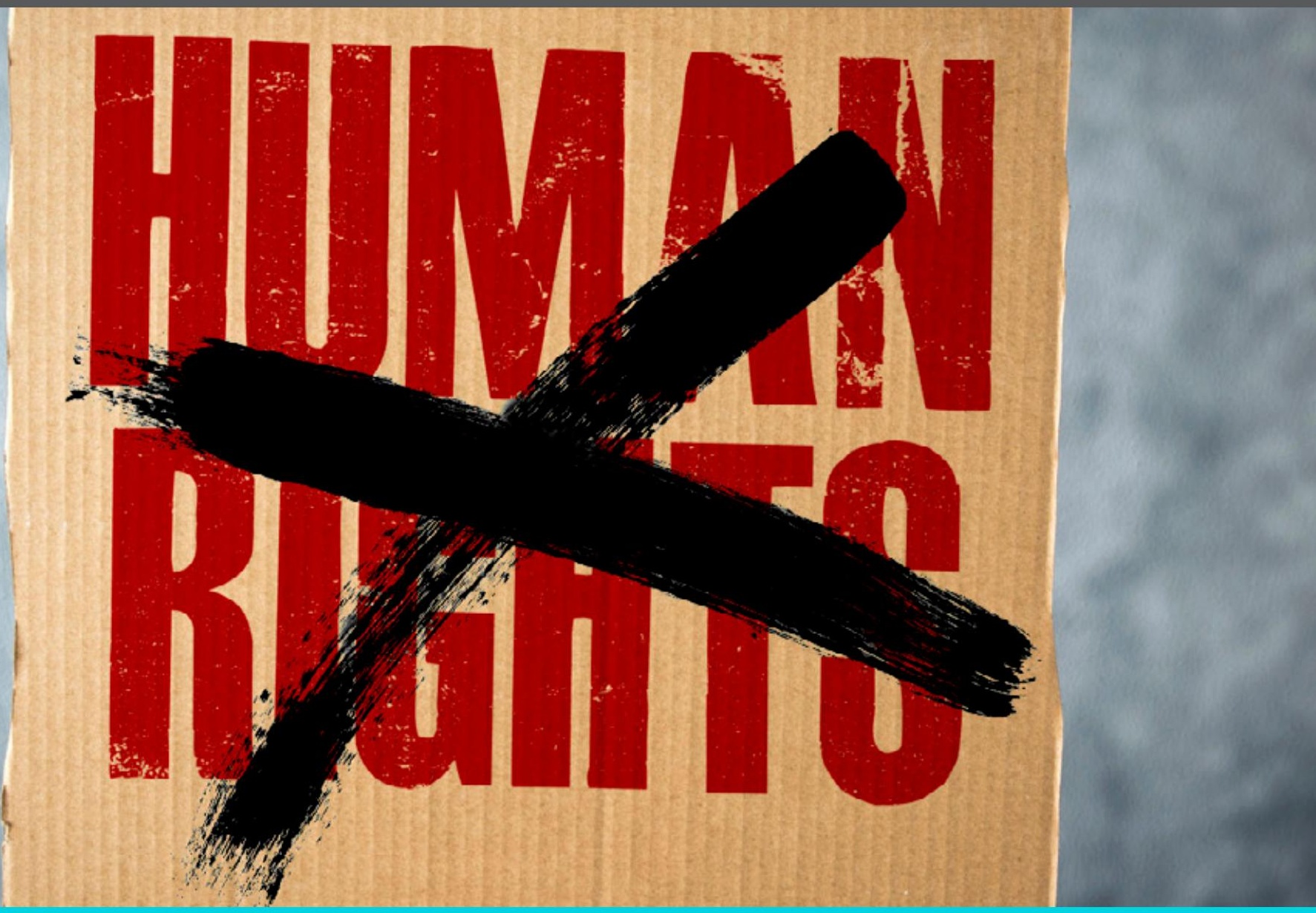

\title{
The Human Rights Act Should Not Be Repealed
}




\section{The Human Rights Act Should Not Be Repealed}

There is no reason to repeal the Human Rights Act and the government's manifesto commitment to do so should be dropped. The objections to it are misconceived, the arguments against it being based either on inaccurate understandings of what it says or error-strewn assertions about the nature of its impact. The political motive for attacking the Act - to undermine the UK's association with Europe - has been overtaken by the much greater European disengagement of BREXIT.

emoval of the direct enforceability of the European Convention on Human Rights in UK law (which would be the effect of the repeal of the Human Rights Act) would be a further - and unnecessarily gratuitous - act of selfharming isolationism by the UK. It would be seen as a deliberately hostile intervention by a Scotland that already finds itself being taken out of the EU against its will and whose devolution settlement has the European Convention as a central hinge. Repeal would destabilise the Good Friday Agreement and further damage relations with the Republic of Ireland, already under strain because of BREXIT. The British Bill of Rights, with which it is proposed to replace the Human Rights Act, is presently without substance and, despite Government promises of consultation, threatens to be merely a 'top-down' Westminster manoeuvre to camouflage the assault on rights that repeal of the Human Rights Act would inevitably entail.

\section{The Political Context}

The Human Rights Act has never been supported by government, even by the Blair administration which secured its enactment. The media have also hated it from the start, blaming it for the development of a law of privacy that hits profits. Then in the mid-2000s just as the Europhobia that was to lead to BREXIT was coming into the mainstream from the political fringe, along came the axe-killer John Hirst, winning a case in the European Court of Human Rights in Strasbourg on the right of (some) prisoners to vote. Now, Strasbourg is not Brussels, and the European Convention has nothing to do with the EU, but it is (continental) Europe. Eurosceptics seized on the Hirst case and quickly made the leap from it to clamouring for the repeal of the UK's Human Rights Act - a measure which had nothing to do with prisoners' voting but which does include the rights in the European Convention within its protective remit. After the Conservative Party's surprise victory in 2015 the country found itself victim not only of the BREXIT referendum but also of a manifesto promise to repeal the Human Rights Act.

Theresa May as Home Secretary has long disliked the Act and has over the years been a leader of the charge for its removal, even suggesting (during the BREXIT campaign) departure from the whole Convention system itself. That dramatic inwards turn - no fewer than 47 states, from Russia to Turkey are members - has been ruled out (at least for now). The Human Rights Act continues to teeter on the brink, with the new Justice Secretary Liz Truss re-committing to its repeal on 22 August. The measure has been the innocent victim of a cross-fire battle in the Conservative party between the Europeanists and the Eurosceptics - hatred of the Act was a proxy for hatred of the European Convention which was in turn a proxy for the real enemy, the European Union. Now the Brussels monster has been slain, even extreme Europhobes must wonder why they should any longer bother with the smaller fry caught on No-Man's Land. It is a meaningless preoccupation for a government and parliament with far bigger self-inflicted worries on its plate.

\section{The Case For Repeal Is Not Made Out}

It might be worth persevering with change if the arguments for repeal had any independent substance to them. In fact they are rooted in a series of false assumptions about the
Act, myths that need to be believed if the argument against the Act is to have any coherence. Here are some basic but frequently ignored truths.

\section{The Human Rights Act} respects parliamentary sovereignty

This is made clear in section 3(2) and again in sections 4 and 6 . Our elected representatives can do whatever rights-violating that they judge to be necessary. Public authorities must execute such wishes, being specifically protected from being successfully sued under the Human Rights Act whenever they can point to a clear mandate from Parliament to do what they are doing. So the judges simply cannot override the rights-violating wishes of Parliament where these are stated in terms that make this consequence unavoidable. It is true that the Act allows judges to be somewhat creative in their interpretation of laws so as to ensure the actions under them do not breach the rights set out in the Act, but it specifically prohibits them from going beyond the bounds of the 'possible' in trying to achieve this (section 3(1)). The judges have followed this instruction to the letter. Even if they didn't the legislature could override them if it so wished.

The drafters of the Human Rights Act protected parliamentary sovereignty because the Labour government behind the measure insisted on it. As a consolation to rights-supporters more fervent than themselves, the law also included a special pseudoremedy where parliament has acted in a direct, rights-infringing way, 'the declaration of incompatibility' (section 4). This allows our top courts to declare a law 'incompatible' with the rights in the Human Rights Act but specifically states that such 'declarations' are to carry no legal impact whatsoever. The government has to revisit the issue after such rulings and consider what, if anything, to do - but it remains master of the process, the courts (and human rights) remaining well below in the pecking order of power.

Breaching human rights remains something of which politicians are not proud, so those declarations that the courts have made have generally been followed up by the government. So with the famous Belmarsh case, where our most senior judges declared the detention without charge of suspected international terrorists to 
be a breach of rights, the government did change things, introducing control orders instead. When Mr Cameron and Mrs May decided to implement a ruling on fairness for people on the sex offenders' register - an emotive topic - they asserted that they were compelled by the courts to do what they were doing. But they weren't, just as Mr Blair's government could have stuck by Belmarsh, they could simply have said that they were intent upon doing nothing.

It is true that the Strasbourg court remains in its oversight position over all UK law while the UK remains a member of the Council of Europe and there are no plans presently to withdraw (whatever the current Prime Minister might have said in the course of the BREXIT campaign). This inevitably means that if the government violates human rights at home it may well end up failing to defend itself successfully in Strasbourg. But this has nothing to do with the Human Rights Act. It is not to be blamed for events that occur elsewhere for which it has no responsibility.

\section{The European Court of Human Rights does not rule over the UK courts}

A further word on the Strasbourg court is called for. Just as parliament wrestled with sovereignty and rights when enacting the Human Rights Act in the late 1990s, so too did it have to work out what to say about the rulings of this body. Strasbourg was (still is) the final court of interpretation on what the Convention meant. On the other hand there was no stomach for making this European institution the top court in the UK. The answer (in section 2) was to make sure the British courts knew about the relevant Strasbourg case-law whilst also making clear they did not have to 'follow' it in the slavish way lower courts do to decisions in the British system further up the pecking order (the doctrine of precedent). After a false start - when the judges here were a bit too overenthusiastic in following Strasbourg the position is now clear that section 2 means what it says: that the judges can depart from Strasbourg where they feel strongly that that court has got it wrong, in for example the laws of evidence in serious criminal trials ( $\underline{R \vee \text { Horncastle) }}$ and the rules on life imprisonment ( $R \vee$ McLoughlin and Newell). The cases where this has happened make clear that this is the privilege of only very senior judges. Strasbourg can then reflect and comment on the UK approach when a suitable case comes along before them (and have done so from time to time). It is much more 'dialogue' than domination. Sure, ignoring Strasbourg might create the problems of non-compliance just referred to with regard to acts of parliament - but that risk is entailed in membership of the Council of Europe, not something the Human Rights Act has caused.

\section{The Human Rights Act protects us all}

The Act is the reason why we all have some protection now from the intrusion of the media into our private lives but it goes well beyond that. If we are in a care home, it is because of the Act that we have a better chance of being treated with dignity and respect. It is because of the Act that public authorities need now to be more careful how they respond to plausible death threats by strangers against those they stalk, and why housing authorities need to be more open to discussion before they make eviction decisions. If we join the armed forces, it is because of the fear of accountability under the Human Rights Act that army chiefs need to be careful before they send us to our deaths in undefended transport vehicles at war or into murderously savage training routines at peace. If those whom we care about die in unexpected ways the Human Rights Act gives us a fighting chance of finding out what really happened, as in Hillsborough or domestic violence or in cases of failure of child protection. The Human Rights Act has also insisted on protections for prisoners, suspected terrorists, asylum seekers and others who are traditionally unable to rely on the law for support. For many, this is reason enough to argue for its retention. But the Act goes much further than that too, reaching everyone. We are all only one unlucky or ill-judged step away from needing the Act.

\section{Fragmenting The United Kingdom}

The Labour government that enacted the Human Rights Act embedded it in the devolution arrangements that were achieved in Scotland, Wales and Northern Ireland in the same year as the measure's enactment. Each model is different but they share a commitment to human rights as a central theme. Of the three, only Wales voted BREXIT with England - the other two were unequivocal remainers. For Westminster now to impose repeal of the Act would be like throwing further petrol on the raging fire of alienation that BREXIT has already started. A conversation about reopening the Irish unity issue has already begun in Ireland. If the Human Rights Act were now to be undone, might space be being unwittingly created for further reneging on past promises by darker forces?

\section{The Bill Of Rights Alternative}

The so-called British bill of rights is merely a camouflage with which to disguise the sharp reduction in rights protection that repeal of the Human Rights Act would necessarily entail. The headline claims will no doubt be loud, but the small print devastating for the principles of universality, justice and fairness that are what the Human Rights Act is all about. The idea of a British bill of rights imposed by Parliament on the whole kingdom is of a piece with the fantasy that drove BREXIT - a lost vision of a homogenous, Westminster-led land in which everyone knew their place. We should celebrate the departure of this vision not legislate to fool ourselves into believing it continues.

Professor Conor Gearty (LSE Law, London School of Economics and Political Science) 
